\title{
Banking and Regulation in Emerging Markets: The Role of External Discipline
}

Xavier Vives

This article reviews the main issues of regulating and supervising banks in emerging markets with a view toward evaluating the long-run options. Particular attention is paid to Latin America and East Asia. These economies face a severe policy commitment problem that leads to excessive bailouts and potential devaluation of claims of foreign investors. This exacerbates moral hazard and makes a case for importing external discipline (for example, acquiring foreign short-term debt). However, external discipline may come at the cost of excessive liquidation of entrepreneurial projects. The article reviews the tradeoffs imposed by external discipline and examines various proposed arrangements, such as narrow banking, foreign banks and foreign regulation, and the potential role for an international agency or international lender of last resort.

Liberalization and integration of financial markets have been associated with an increase in capital movements and with the financial crises. In particular, surges in foreign short-term debt have been blamed for crisis episodes in emerging economies in Asia (Thailand, Indonesia, and the Republic of Korea) and Latin America (Mexico, Brazil, Ecuador, and Argentina), as well as in the periphery of Europe (Turkey). These crises have proved costly in terms of output.

Several policy responses have been suggested. Among them have been the reduction of short-term debt, the development of stock markets, the improved regulation and supervision of domestic financial system, enhanced transparency requirements and market discipline, and the establishment of an international lender of last resort. A catalog of "solutions" has been proposed to take care of the problems of banking in emerging market economies including moving to a narrow bank system, building a currency union, and leaving banking in the hands of foreign banks and offshore institutions.

This article identifies policy responses tailored to the needs of emerging market and developing economies. The question is whether the regulatory policies and

(C) The Author 2006. Published by Oxford University Press on behalf of the International Bank for Reconstruction and Development / тHE WORLD вANK. All rights reserved. For permissions, please e-mail: journals.permissions@oxfordjournals.org. doi:10.1093/wbro/lkl002 Advance Access publication August 5, 2006 
practices of developed economies can be recommended essentially without change or whether a different policy mix is needed. A basic theme is that more acute asymmetric information problems and a weak institutional structure in emerging market economies call for policy prescriptions that differ not only from those of developed economies but also across emerging market economies.

Attention is focused on a particular consequence of the weak institutional structure in emerging countries: the lack of capacity for policy commitment. This lack of capacity for commitment may be due to the short horizons of public officials in the face of, for example, political instability. The outcome is that the government of an emerging market economy may bail out the private sector, encouraging excessive risk taking, or devalue the claims of foreign investors, discouraging their investment in the first place. Indeed, a major problem in emerging markets is the implicit or explicit guarantee of a bailout in the event of a banking crisis, as experiences in Argentina, Mexico, and Thailand show, or the use of inflation to devalue domestic currency-denominated claims. ${ }^{1}$

The result is that domestic regulation may not be enough in countries that face a commitment problem, and those countries may have to import discipline. However, some ways of importing discipline, such as increasing the role of short-term foreign debt, have costs. The article examines the tradeoffs imposed by different ways of importing discipline and classifies countries according to the desirability of doing so. It analyzes the catalog of solutions to the problems of financial systems in emerging market economies and the potential role of an international agency such as the International Monetary Fund (IMF).

\section{Banking in Emerging Market Economies}

What makes banking regulation different in emerging market economies? Why do these countries require different regulatory and supervisory arrangements?

\section{The Role of Banks and Fragility}

Banks provide transaction and payment system services, insurance, and risk sharing (transforming illiquid assets into liquid liabilities). A central function of banks is the financing and monitoring of entrepreneurial projects, which are illiquid and opaque because of asymmetric information problems such as moral hazard and adverse selection. ${ }^{2}$ Some entrepreneurial projects cannot obtain market financing because no credible information on them can be conveyed to the public domain. A bank can accumulate relationship-specific skills to monitor those projects and be able to finance them. In this way the banking system helps overcome problems associated with asymmetric information in an economy. 
Asymmetric information problems are bound to be more acute in emerging market and developing economies. The production of information is more problematic in emerging market economies because of institutional factors. Indeed, emerging market economies fare poorly on the indicators of rule of law, the protection of property rights, and accounting standards, pointing to aggravated moral hazard and adverse selection problems. Furthermore, the production of information, which typically involves a fixed cost, is discouraged by the normally small size of the emerging market.

One direct consequence of the enhanced asymmetric information problems is that the financial system is less developed because the cost of setting up well-functioning markets is higher. Arms-length finance just does not work. A derived consequence is that the role of the banking system, in particular the monitoring of entrepreneurial projects, is much more crucial. Indeed, for most companies in an emerging market economy the only possible source of finance, except for earnings, is bank loans. Banks and their monitoring capacity are therefore at the center of economic development, and their potential fragility may dramatically worsen downturns. The crises of Mexico, East Asia, and Russia provide examples, as well as the more recent crisis in Argentina.

Why are banks fragile? The essence of banks is that they create liquidity, which leaves them vulnerable to runs. Banks protect entrepreneurs that need finance from the liquidity needs of depositors and investors. There are different versions of the story, but this is the cornerstone of modern banking theory (Diamond and Dybvig 1983; Holmström and Tirole 1997, 1998; Diamond and Rajan 2001). ${ }^{3}$ Firms may be unable to obtain funding because of asymmetric information, as they do not have enough pledgeable income (the fraction of their return that can be committed to be paid to outsiders). Banks come to the rescue, for example, by creating liquidity holding collateral and committing to make payments (Holmström and Tirole 1997, 1998). In short, the standard deposit contract and loan provision to opaque entrepreneurial projects are complementary and central to the function of a bank.

Short-term debt-a deposit redeemable at par-leaves banks exposed to failure when returns are low. However, this possibility has desirable incentive properties because it can create an incentive to exert effort for self-interested bank managers who are, put simply, interested mostly in the continuation of their jobs. This is reasonable when the private benefits of control loom large, as may well be the case in emerging market economies with a weak institutional structure. In general, shortterm debt has a disciplining effect in the presence of moral hazard. Indeed, in the extreme, the repayment of long-term debt may not be enforceable, and payment to the creditor may be ensured only by the threat of liquidation in an interim period (Bolton and Scharfstein 1990; Hart 1995). ${ }^{4}$

How does the theory relate to the trend in the banking industry of developed economies moving from the traditional business of taking deposits and granting 
loans to the provision of services to investors (investment funds, advice, and insurance) and firms (consulting, insurance, mergers and acquisitions, underwriting of equity and debt issues, and risk management)? Banking in industrial countries is in a process of transformation (more advanced in the United States than in Europe), where the financial margin makes way for fee and commission revenue. Indeed, the share of assets held by banks relative to nonbank intermediaries is declining in developed economies (Allen and Santomero 2001). In contrast, in emerging market economies the traditional role of banks remains central.

In summary, in emerging market economies the traditional function of banks is all the more important, because financial markets are less developed and asymmetric information problems are more acute.

\section{Fragility, Regulation, and the Safety Net}

The inherent fragility of the banking system, with asymmetric information at its root, leads to the failure of institutions, panic, and systemic crises that can have a major impact on the economy. The great depression of the 1930s is a good example, and more recent episodes of financial crises in the United States, Scandinavia, Mexico, East Asia, and Russia remind us of the potential for economic disruption. The failure of a bank has adverse consequences on nonfinancial firms precisely because individual bank-firm relationships are valuable (Petersen and Rajan 1994). In fact, even a contraction of bank capital may result in a credit crunch, with severe disruption to the private sector. This is especially evident in an emerging market economy, which is more dependent on the intermediary services of banks.

At the base of the fragility of banking is the coordination problem of depositors, who may decide to call back their short-term deposits and make a sound bank fail. The literature has two views of crises: the multiple-equilibrium panic view (Diamond and Dybvig 1983) and the information-based view (Gorton 1985, 1988; Jacklin and Bhattachrya 1988). According to the first, runs are triggered by events unrelated to the fundamentals, whereas according to the second, runs are triggered by bad news about the assets of the bank. Recently, those views have been reconciled by introducing asymmetric information and linking the probability of a run to the strength of fundamentals (Morris and Shin 2000; Rochet and Vives 2004; Goldstein and Pauzner 2005). ${ }^{5}$

Thus, a solvent bank may be subjected to a purely speculative panic, with depositors withdrawing funds and the bank being forced to quickly liquidate assets at a high cost. The cause of the problem is the dependence of banks on short-term debt (or the standard deposit contract). In addition, there is the danger of systemic risk owing to contagion from the failure of one entity, which may give rise to a strong negative externality both for the financial sector and for the real sector of the economy. For example, the failure of one entity may, through interbank market commitments, 
lead to the failure of others (Allen and Gale 2001). Similarly, large variations in the price of assets, such as an abrupt fall in the stock market or the failure of a main intermediary, may generate a domino effect and systemic crises affecting the payment system.

In general, competitive banking will be excessively fragile, and the lender of last resort facilities and prudential regulation (discussed in the following section) will come to the rescue. The aim of regulation has been to provide the banking and financial systems with stability to avoid the negative effects associated with failing institutions and systemic crises. Other aims have been to protect the small investor and to promote the competitiveness of the system.

\section{The Lender of Last Resort and the Policy Commitment Problem}

In industrial countries the lender of last resort and deposit insurance are basic to the stability of the banking system. There is a tendency, however, to protect banks and depositors above the levels required by the deposit insurance, in particular, under the too-big-to-fail policy. One reason is the potentially systemic consequences of the failure of a large institution, but more often help is a reflection of a time-inconsistency problem in the presence of a moral hazard problem. A well-intentioned lender of last resort - the central bank - will find it optimal ex post to help whenever this salvages the value of projects, whereas bankers, anticipating the help, will tend to exert suboptimal effort, creating a moral hazard situation because the central bank is unable to observe the banker's level of effort in monitoring projects.

The time-inconsistency problem faced by a central bank arises because ex ante the central bank may want to commit to closing the bank if the returns are low (signaling a solvency problem), whereas helping the bank if the returns are only moderately low (signaling a liquidity problem). Such a commitment provides incentives for bank managers to monitor the projects they finance. In this way the central bank may implement the second-best solution in a competitive banking system. ${ }^{6}$ However, ex post, costly liquidation of the projects may not be optimal, so the central bank may hesitate to carry out its threat. The commitment problem is compounded by the interest of a bank manager in the continuation of the bank. Building a central bank with a "tough" reputation can alleviate the time-inconsistency problem.

This commitment problem because of intertemporal inconsistency is aggravated in emerging market economies where institutions are weak and suffer from a lack of credibility and independence. It is difficult for central banks to build a reputation for disciplining banks because the central banker's effective horizon is short because of political instability. For example, in Argentina in the 1980s the average term in office for a central bank governor was less than a year although the legal term was four years (see Cukierman 1992, chapter 19). A related problem is the lack of legal protection for bank supervisors who attempt to impose discipline (again as in Argentina). 
Then, even if the perceived problem is serious, the bank may be allowed to continue or even be granted help (World Bank 1998). A weak institutional structure allowing the regulated to unduly influence the regulators (regulatory capture) also explains why failure does not lead to a change of management. "Crony capitalism," where the government helps firms that are considered friends, is an extreme form of capture.

The consequence of the intertemporal inconsistency and regulatory capture is that the central bank of an emerging market economy that has a commitment problem will have incentives to induce inflation to reduce the real value of nominal debt commitments when banks or entrepreneurs are in trouble. This will avoid project liquidation, but it destroys incentives to exert effort and, in turn, devalues foreign investments in domestic currency. The outcome is a lack of foreign investment. As argued below, foreign-denominated short-term debt may be crucial for the access of an emerging market economy to international capital markets because it protects foreign investors from the devaluation of their claims by the actions of the government.

\section{Prudential Supervision}

The too-big-to-fail policy, deposit insurance, and, in the extreme, blanket protection and bailouts introduce distortions into the decisions of financial entities. They reduce the incentive of depositors to monitor bank performance and, coupled with the bank's limited liability, they give rise to excessive risk taking. Bailouts eliminate the disciplining effect of closures and exacerbate risk taking and inadequate monitoring by bank managers.

The need for regulation is particularly acute when charter values ${ }^{7}$ are low (and therefore incentives to take risk are high), and the social cost of failure is high (and therefore banking failure has a large impact). With either high disclosure requirements or risk-based insurance, banks pay for taking more risk, and capital requirements have a chance to be a sufficient instrument for controlling risk taking (table 1; see Diamond and Rajan 2000 for the role of bank capital in controlling excess fragility). Otherwise, capital requirements may need to be complemented with restrictions on the investments of banks to check risk taking.

Capital requirements together with supervision and market discipline are the three pillars of bank regulatory reform. The general trend in bank regulation is to check risk taking with capital requirements and appropriate supervision. Both riskbased (deposit) insurance and disclosure requirements have been proposed to limit risk-taking behavior (top and the bottom rows of table 1). Developed economies have tended to move in that direction. This movement has been accompanied by a reform of the 1988 Basel Accord on capital requirements to better adjust them for risk (Basel II). Basel II contemplates that banks can adopt either a "standardized" approach to capital requirements in which external rating agencies set the risk weight for different types of loans (say corporate, banks, and sovereign claims) or an 
Table 1. Possible Banking Regimes, the Incentives to Take Risk, and the Necessary Regulatory Instruments When Charter Values are Low and the Social Cost of Failure Is High

\begin{tabular}{|c|c|c|c|}
\hline \multirow[b]{2}{*}{ Banking regimes } & \multicolumn{2}{|c|}{ Risk-taking incentives } & \multirow[b]{2}{*}{ Regulation } \\
\hline & Liability (rates) & Asset (investment) & \\
\hline $\begin{array}{l}\text { Free banking, observable } \\
\text { risk/high disclosure }\end{array}$ & Medium low & Absent & Capital requirements \\
\hline $\begin{array}{l}\text { Free banking, unobservable } \\
\text { risk/low disclosure }\end{array}$ & Medium high & Maximal & Capital requirements and asset restrictions \\
\hline Risk-insensitive insurance & High & Maximal & Capital requirements and asset restrictions \\
\hline Risk-based insurance & Low & Absent & Capital requirements \\
\hline
\end{tabular}

internal rating-based approach in which banks estimate the probability of default (and also the loss, given default, in an advanced version of the method). The idea is to calibrate the capital requirement so that it covers the value at risk (expected and unexpected) from the loan under some assumptions.

It must be noted, however, that transparency has its limitations. Whereas it is feasible to introduce the disclosure requirements of the market positions of banks, it is more difficult to assess the risk level of the illiquid loan portfolio of a bank. Furthermore, more disclosure may induce information-based runs of investors, generating instability.

\section{Regulation in an Emerging Market Economy}

If it is feasible to introduce risk-based insurance and disclosure requirements that eliminate moral hazard, capital requirements (risk-based themselves) may be a sufficient instrument to check risk taking and improve welfare (table 1). However, the characteristics of an emerging market economy cast doubt on the feasibility of such a strategy.

First, an emerging market economy is likely to face considerable uncertainty in terms of high economic volatility, high direct and indirect exposure to exchange rate risk, high maturity and currency mismatch, and high nondiversifiable risk in a typical loan portfolio. Two sources of increased risk are the high proportion of debt in foreign currency and of debt of short maturity (the reasons are explained later). The risk of high (and variable) inflation is, in a first instance, at the base of the use of those instruments. Furthermore, higher levels of risk are hidden behind the (false) security of a pegged exchange rate. For example, a bank feels protected because it has matched a dollar liability with a dollar-denominated loan without realizing that if the borrower earns income in pesos, a collapse of the peso will provoke a default. The currency 
match has hidden credit risk. If the bank does not match a dollar deposit with a dollardenominated credit, it becomes exposed directly to exchange rate risk.

Second, as noted, financial markets are less developed, and the monitoring role of intermediaries is enhanced in emerging market economies. The production of information on private sector activities and the general contracting environment are problematic. The background of these problems is the lack of economies of scale in the production of information and severe moral hazard and adverse selection problems. This implies, at the same time, that markets are thin and that the generation of information and contract enforcement roles rely relatively more on financial intermediaries. A further consequence of the thinness of financial markets is that banks have a high exposure to public debt (for example, government bonds) and are therefore vulnerable to inflationary strategies of the government and may be less able to match long-term investments by issuing appropriate liabilities (maturity mismatch). Short-term debt leaves banks and firms exposed to sharp increases in interest rates in response to a currency devaluation. At the same time a bank may have a harder time diversifying its portfolio because default probabilities may have a high correlation across projects. An obvious case is the collapse of the exchange rate.

All of these factors point to a riskier environment for banks. A currency crisis leads to a financial crisis and to strong effects in the real sector. A depreciation of the currency leads to a deterioration of balance sheets for firms and banks and to a decline in the net worth of the private sector. Because of asymmetric information problems, this decline in net worth will lead to a credit crunch, and banks with weak balance sheets will cutback on lending, exacerbating moral hazard and adverse selection problems (see Bernanke and Gertler 1989 for the general mechanism and Mishkin 1999a, 1999b for an application to the Tequila crisis in Mexico). A weak banking sector can also lead to a currency crisis. Kaminsky and Reinhart (1999) found that banking sector trouble typically precedes a currency crisis and that the currency crisis aggravates the banking crisis in a self-reinforcing manner. Finally, underdeveloped financial markets and no sound contracting environment increase the social cost of failure and the liquidation of projects. This means that the real effects of financial crises are multiplied.

Third, an emerging market economy will tend to have a weak supervisory structure. The reasons are rooted in the same factors that keep financial markets underdeveloped: the difficulty producing information and enforcement problems aggravated by the lack of protection for supervisors. Supervisors are either more easily corrupted, because of the lack of resources and low salaries, or more vulnerable to retribution if they do not acquiesce to the demands of lobbies, because of the lack of effective legal protection. Symmetrically, some banks may see how expropriatory regulatory decisions are made, perhaps because of their weaker political position, and this will induce a high rate of discounting. The consequence will be low charter 
values as part of the bank profit is diluted, and this will happen even with a relatively low level of competition. The consequence will be enhanced incentives to take risk.

The characteristics of an emerging market economy of high uncertainty, increased likelihood and incidence of financial and currency crises, predominant financial role of banks, and weak supervisory structure lead to the policy conclusion that the regulatory strategy needs to be adapted to these conditions and to protect the fundamental role that banks play. Indeed, these characteristics make it much more difficult to follow the industrial country regulatory strategy in an emerging market economy. First, because information problems are more acute and the production of information is more problematic, it is more difficult to move toward a disclosure strategy. Second, risk-based deposit insurance can work only when insurance can be priced according to objective indicators of bank risk. Those indicators may be more difficult to obtain in an emerging market economy (they are difficult to obtain even in a developed economy). This makes the move toward a risk-based insurance strategy more difficult. Furthermore, the application of Basel II criteria to emerging market economies may be problematic. As Powell (2001) noted, these economies will have difficulty implementing the internal rating approach, especially because the new standards have not been calibrated for the environment in these countries, and so they will tend to adopt the standardized approach. But with the limited number of rated institutions in emerging market economies, this will mean little change from the current situation. Yet the problem of building a better link between risk and capital is, if anything, more acute there.

The corollary is that the regulation of banking and financial markets must be adapted for emerging market economies. Reliance on transparency and disclosure requirements as well as risk-based insurance and capital requirements is limited. Capital requirements in particular will need to be adapted to the conditions of emerging market economies (for example, public debt is risky because of inflation) and, most likely, complemented by other restrictions on the activity of financial institutions. At the same time, because of the high cost of the liquidation of projects and the social cost of failure in emerging market economies, competitive pressures and market discipline should not be set at the same level as in developed economies.

A broader consequence of the weak institutional structure of emerging market economies is that the policy commitment problem becomes central for attracting foreign capital. This problem and how external discipline can help overcome it are discussed in the following section.

Argentina coped with a policy commitment problem by importing external discipline through its currency board's "hard peg" (a fixed exchange rate backed by foreign reserves) and adopted a market discipline model (high disclosure levels, subordinated debt, limited deposit insurance, and risk-based capital requirements). Argentina was following a modern industrial country strategy anchored in the currency board (it was moving toward the top line of table 1 , free banking with disclosure). The obvious 
question is whether this model is feasible once the currency board has collapsed and the anchor has disappeared. The banking and currency crises were derived from the nonsustainability of the currency board in a recessionary context and with the underlying problems in Argentina, such as the lack of the credibility of institutions and the protection of property rights. The crisis was more like an informed run (such as that after the Tequila crisis) than a crisis derived from the moral hazard of bank managers or a coordination failure of the expectations of depositors. The financial system was reasonably well regulated and the currency board, when credible, provided discipline, thereby limiting excessive bailouts (see Calvo, Izquierdo, and Talvi 2003 for further details of the crisis).

\section{The Policy Commitment Problem and External Discipline}

The government of an emerging market economy may devalue the claims of foreigners in domestic currency to protect the domestic private sector. This lack of policy commitment capacity derived from a weak institutional structure is a central problem for an emerging market economy that needs access to the international capital market. In a similar vein Tirole (2002) argued that the central market failure in external borrowing for an emerging market economy is the lack of contracting capacity between its government and foreign investors.

It has already been shown how short-term debt has a disciplining effect when there is a moral hazard problem, whether it is from the side of the entrepreneur seeking credit to finance a project or the banker monitoring a loan. This gives scope for a central bank in a competitive banking system to provide help in a range of returns while maintaining incentives by denying help when returns fall below the optimal critical threshold. The problem arises, however, that while ex ante it is optimal to commit not to help when returns are low, ex post, once effort decisions have been made, it is optimal to help avoid costly liquidation. A central bank with no policy commitment capacity will have incentives to induce inflation to reduce the real value of nominal debt commitments when banks or entrepreneurs are in trouble. This will avoid liquidation but destroy incentives to exert effort and discourage foreign lenders, who may see their claims devalued.

But to implement the second-best solution, a central bank must be able to commit not to help when returns are low. External discipline may come to the rescue (Vives 2002). An extreme form of importing external discipline, examined here for illustrative purposes, is "dollarization."

\section{Dollarization}

Dollarization represents a commitment to a limited use of the lender of last resort facilities. Dollarization means that banking contracts are in "real" (dollar) terms. In a 
dollarized regime help for the banking system (bailouts) must be arranged in advance, through stabilization funds or tax schemes, or precontracted in the international market. For example, when Argentina adopted a currency board in 1991-2001, it also established a contingent liquidity facility with international banks. Banks were also required to meet new liquidity requirements and to hold excess reserves, because the Convertibility Law of 1991 and the Charter of 1992 severely restricted the central banks' lender of last resort activity (Calomiris and Powell 2000). Most currency boards have established limited lender of last resort facilities. A stabilization fund can provide liquidity when needed, but it can be diverted (as happened in Mexico and Thailand).

Dollarization represents a commitment because it is costly to reverse. A currency board or a hard peg, as Argentina's recent experience suggests, represents a lesser commitment. Typically, the currency board is established by law (as in Argentina) and therefore can be dissolved by another law, which does, however, raise the cost of getting rid of the arrangement.

What are the costs and benefits of dollarization in a small open economy? In a competitive banking environment, projects are liquidated when the returns of the bank cannot cover the promised payment to depositors. However, in this competitive banking solution, there is typically excessive liquidation. The liquidation threshold imposed by a competitive banking environment is stricter than the second-best threshold because of risk sharing (a competitive bank has to promise a relatively high return to depositors that want to withdraw early to insure themselves although returns are higher in the long term) or because of a coordination failure among investors that induces a run on the bank. The excessive liquidation problem may be particularly acute if the coordination problem of investors is severe (Gale and Vives 2002).

The result is that dollarization provides a commitment not to help at the cost of not helping in circumstances where it would be optimal to do so ex ante. Therefore, dollarization is a third-best solution. Refusing help to the private sector creates incentives for managers to exert effort, but the probability of default implicitly chosen by the market may be much higher than the incentive-efficient level required to encourage managerial effort.

Partial dollarization can be a risky strategy. A bank may acquire dollar-denominated debt, accepting domestic dollar deposits or issuing dollar-denominated certificates of deposit in the international market. This opens the door to partial dollarization. In theory such an arrangement could deliver an optimal allocation of risk while providing incentives for bank managers to exert effort (Gale and Vives 2002). In practice, however, partial dollarization suffers from credibility and instability problems. The convertibility of dollar deposits by domestic residents can be suspended in a crisis. Furthermore, once banks accept dollar deposits, they are likely to make dollardenominated loans to domestic residents (to avoid exchange rate risk and because they have a comparative advantage serving domestic customers). Credit risk will then resurface as residents earning the domestic currency have trouble paying the 
dollar-denominated loans if the domestic currency depreciates. In fact, in trying to help by inducing inflation, the central bank may cause a devaluation of the currency, bankrupting the dollar-indebted households. The problem may be compounded by self-fulfilling expectations of a banking crisis.

\section{Foreign Short-Term Debt}

Another way of importing external discipline is by acquiring foreign short-term debt. Short-term debt denominated in domestic currency will lose its disciplining effect if the central bank can devalue the currency through inflation when trouble arises. This is not the case with short-term debt denominated in foreign currency. Entrepreneurs in the small open economy may want to commit to high effort by borrowing in foreign currency. They will do so if the lower interest rate obtained with foreign debt more than compensates for the expected cost of liquidation (Jeanne 2000). Similarly, short-term debt ameliorates the default problem of an opportunistic populist government that repays debt only if it is in its short-term interest to do so and if default is costly. Taking foreign short-term debt may be good in a country prone to populist governments (Rodrik and Velasco 1999).

Consider an emerging market economy that has acquired foreign-denominated short-term debt to alleviate the moral hazard and commitment problem to access the international capital market. This short-term debt serves to discipline the private sector to exert effort to improve returns and to prevent the government from devaluing the claims of foreign investors. This allows access to the international capital market in amounts beyond the country's reserves (Although the borrowing capacity of the emerging market economy country is still limited by its international collateral [Caballero and Krishnamurthy 2002, 2003]).

When returns are below a certain threshold, projects should be restructured to provide incentives to exert effort. The market may result in excessive liquidation of entrepreneurial projects, because of the coordination failure of investors, for example. This will always happen when the moral hazard problem in the country is moderate (implying a low restructuring threshold for returns). In this case, and to preserve incentives, projects should not be foreclosed when the country is insolvent but not too close to the solvency threshold. Instead, the market will foreclose except when the country is well above the solvency point. However, when the moral hazard problem is severe (implying a high restructuring threshold for returns), a solvent country may need to restructure when returns are close to and above the solvency threshold. Then the coordination failure of international investors may be a blessing in disguise because it may enforce the optimal restructuring threshold. That is, it may (although it need not) provide optimal incentives ex ante (Rochet and Vives 2004).

Foreign short-term debt is a two-edged sword. It works as a disciplining device but leaves the door open to systemic risk, speculative attack, and a sudden reversal of 
capital flows. This means that in a country that faces a moral hazard problem overexposure to foreign short-term debt is possible but that in general its optimal amount will not be zero provided that there is no extreme moral hazard problem. Obviously, the optimal amount of foreign-denominated debt will also depend on the size of the tradable sector in the economy, which determines the amount of effective international collateral that the country can pledge.

Another reason to issue foreign short-term debt is risk sharing when foreign investors are risk-averse. This is akin to the risk-sharing role of the standard deposit contract that a bank offers to its risk-averse depositors. In this case the issuing countries absorb part of the risk and can obtain more favorable terms with respect to expected repayment than borrowing long term. Broner, Lorenzoni, and Schmukler (2004) provided a model where the maturity structure of the debt arises as the resolution of a risk-sharing problem between the government and bondholders. The government of an emerging market economy lowers the probability of a liquidity crisis, shifting risk to bondholders, by issuing long-term debt. This risk is reflected in equilibrium in a higher risk premium and cost of borrowing. In consequence, the government faces a tradeoff between safer long-term borrowing and cheaper shortterm debt. Broner, Lorenzoni, and Schmukler also provided evidence of this effect, particularly in times of crisis when the term premium increases and issuance shifts toward shorter maturities.

Empirical results are mixed. Sachs, Tornell, and Velasco (1996) and Frankel and Rose (1996) found either weak evidence or no statistical effect of short-term debt on crises. Eichengreen and Rose (1998) found that higher levels of short-term debt decrease the probability of banking crises. Radelet and Sachs (1998) and Rodrik and Velasco (1999) found that the ratio of short-term debt to reserves is a robust predictor of financial crisis (sharp reversal of capital flows). ${ }^{8}$ Finally, Detragiache and Spilimbergo (2004) found that short-term debt increases the probability of a debt crisis (although, obviously, this could also be interpreted as more fragile countries having to borrow short term).

A potential alternative to external discipline is financial indexation to some domestic price level. This has been tried in Chile with the Unidad de Fomento (unit of account). The problem is that any index is bound to be imperfect when the economy experiences large swings in relative prices (Calvo and Talvi 2005).

In summary, external discipline through a relatively large amount of foreign short-term debt will be good in emerging market economies or developing countries with a policy commitment problem in which (a) there is a significant but not extreme moral hazard problem, (b) monitoring effort by bankers and entrepreneurs is important for improving returns, and (c) the cost of liquidating projects is not large.

The optimal amount of foreign short-term debt will presumably increase with the size of the tradable sector and the effectiveness of effort by managers in improving returns and decrease with the cost of liquidating projects. 
Candidates for external discipline are countries with a long way to go in political stability, rule of law, contract enforcement, and institutional development and supervision, and those that rely on bank monitoring to make finance available for entrepreneurial projects. At the same time the moral hazard problem cannot be hopeless, and liquidation costs cannot be high. The analysis points to an intermediate range of countries with a weak institutional structure but without an extreme agency problem. Politically stable countries with a modern institutional structure and deep financial markets need not import external discipline.

\section{Assessing the Tradeoffs of External Discipline}

For a range of emerging market economies, this section summarizes some rough indicators, based on Gale and Vives (2002), of the policy commitment problem and the determinants of the welfare analysis of importing external discipline: moral hazard, importance of effort for returns, and cost of liquidating projects.

The economies considered are Argentina, Brazil, Chile, Colombia, Ecuador, Mexico, Peru, Uruguay, and Venezuela in Latin America; Hong Kong (China), Indonesia, Malaysia, Philippines, Singapore, the Republic of Korea, Taiwan, and Thailand in Southeast Asia; and Turkey. Attention focuses on Latin America and Southeast Asia (although Turkey, on the periphery of Europe, is also considered).

An indicator of the extent of the commitment problem is given by the credibility of the central bank. A combined index (see Cukierman 1992, table 21.1) of legal independence, actual turnover of the central bank governors, and a response by experts to a questionnaire can be used to assess the overall credibility and reputation of a central bank. The combined index (weighting the three indexes by their relative contribution in explaining the variations in the rate of depreciation of the value of the currency) provides a ranking of central bank independence of 46 countries during the 1980s. At the bottom are economies such as Argentina, Brazil, Chile, Turkey, Venezuela, Mexico, Peru, Uruguay, the Republic of Korea, and Indonesia. Above these are the Philippines and Thailand. However, the Philippines has the same level of overall central bank independence as Kenya, and Thailand has the same level as Greece. Developments since the 1990s may qualify the situation for some countries (for example, Chile). If we only look at the actual turnover of governors (for the period 1950-89) as an index of credibility, the situation is not different (see Cukierman 1992, table 19.4).

The severity of the moral hazard problem for the bankers or entrepreneurs can be proxied by a battery of legal indicators reflecting the rule of law in different countries (La Porta and others 1998). These include the indicators of the efficiency of the judiciary system, the law and order tradition of the country, corruption, the risk of expropriation, and the risk of contract repudiation by the government, as well as a 
rating on accounting standards. Low marks on these indicators would suggest a severe moral hazard problem for the banker. For example, in countries with poorly defined or poorly defended property rights, some of the bank's marginal returns will be captured by others, which increases the marginal cost of ensuring high returns. Gale and Vives (2002, table 1) classified the marks given in La Porta and others (1998) as low, medium, and high. Under this classification, Peru, Indonesia, and the Philippines (and perhaps Venezuela and even Uruguay) have a severe moral hazard problem. Argentina, Brazil, Chile, Colombia, Ecuador, Mexico, the Republic of Korea, Taiwan (China), Thailand, and Turkey have a significant but not extreme moral hazard problem. Hong Kong (China), Malaysia, and Singapore have a moderate moral hazard problem.

There is also a link between the (indirect) moral hazard indicators (related to the rule of law and accounting standards) and the importance of effort by the banking manager to obtain returns. In countries with a severe or significant moral hazard problem with the firms in the private sector, suggested by low marks in the rule of law indexes, effort by the bank manager to obtain returns will also be important. This means that moral hazard is bound to be a problem in the set of economies considered here, perhaps with the exception of Hong Kong (China), Malaysia, and Singapore. The importance of monitoring efforts by the private sector (bank managers or entrepreneurs) to obtain project returns could also be proxied by the importance of banks in the financial system. This can be measured by the amount of bank assets to total financial assets. In the economies of the sample, only the Republic of Korea is below a ratio of 50 percent (data are unavailable for Hong Kong, China, Indonesia, and Singapore).

The cost of liquidation of projects can be approximated by the level of rights of creditors (high creditor rights are linked to a lower cost of liquidation of projects) and the level of development of the financial system (more developed financial systems can cope better with adverse selection problems at the root of costly liquidation). The level of development of the financial system can be approximated by the ratio of credit to the private sector to GDP, the ratio of stock market capitalization to GDP, and accounting standards. A combination of those indicators yields the following classification for the cost of liquidation:

- High: Peru, Uruguay, and Venezuela.

- Medium high: Argentina, Brazil, Colombia, Mexico, and Turkey.

- Medium low: Ecuador, the Philippines, and Indonesia.

- Low: Chile, Hong Kong (China), Singapore, the Republic of Korea, Malaysia, Thailand, and Taiwan (China).

It is worth noting the regional difference between Latin America (with the exception of Chile) and East Asia. This would be consistent with the better-than-expected recovery of Southeast Asia from the last financial crisis. 
The indicators point to a middle range of economies where external discipline can be a good idea. Those economies are at the intersection of a significant or moderate moral hazard problem with medium-low or low cost of liquidation. Among them are some Latin American countries, such as Chile and Ecuador, as well as some East Asian tigers, such as Hong Kong (China), Malaysia, the Republic of Korea, Singapore, Taiwan (China), and Thailand. Peru, Indonesia, and the Philippines (Venezuela and even Uruguay) are not included because of the severity of the moral hazard problem, to which a potentially high cost of project liquidation is added for Peru, Uruguay, and Venezuela. A medium-high cost of project liquidation is found for Argentina, Brazil, Colombia, and Mexico, as well as Turkey. Those would be candidates for a high dose of external discipline because of the potential benefit to be derived, but the cost would also be high. At the same time Hong Kong (China), Malaysia, and Singapore would derive less benefit from external discipline because the monitoring of projects is relatively less important and the moral hazard problem less severe.

\section{A Catalog of Proposals}

Various proposals are frequently made to solve the banking and regulatory problems of emerging market economies. This section briefly surveys some of these-narrow banking, monetary union, foreign banks, public banks, and offshore banking—and argues that none of them is a panacea that can provide the desired solution.

\section{Narrow Banking}

Narrow banking has been proposed to solve the instability problem and to limit the exposure of insurance funds and taxpayers to banking trouble. The extreme of a narrow bank is one that holds 100 percent reserves. Friedman (1959) advocated such banks (and proposed that reserves be remunerated). Other proposals would have the bank invest only in safe short-term securities (such as U.S. Treasury bills). Deposit insurance would then serve only to protect against fraud, and nonbanks would not be insured. In this scheme a financial holding company could have two subsidiaries: a narrow bank arm (mutual fund) and a finance company arm that would grant loans and fund them with uninsured liabilities (Litan 1987). Other proposals would allow the bank to take more risk.

The basic idea is to convert the bank into a mutual fund that provides liquidity and dominates the traditional bank in the deposit dimension. Indeed, in a mutual fund where the investor is promised a share of the value of the fund, there is no incentive to run. Deposit insurance is unnecessary (except perhaps to protect against fraud) and need not generate moral hazard. The case for the narrow bank is buttressed by the increasing process of securitization of credits, by some studies that 
conclude that economies of scope between deposit and lending are small (Pulley and Humphrey 1993), and by advantages in the control of the money supply (however, the last two conclusions are disputed by Benston in Fernandez and Schumacher 1997).

With sufficiently developed financial markets, the criticisms that a narrow bank may not have enough safe assets available to invest or that there would be insufficient funds left to finance long-term projects are unlikely to hold, but they do have force in emerging market economies with an underdeveloped capital market. However, there is a deeper criticism of the proposal: narrow banking throws away the baby with the bath water. That is, it destroys the financing of illiquid loans with liquid liabilities (see Wallace 1996 for a version of this argument). These are mostly business loans, which are opaque and nonsecuritizable, in contrast to mortgages and consumer credit. As already shown, the fragile structure of banks allows them to create liquidity for business. Indeed, there is evidence that deposit taking and loan provision go together. Nakamura (1988) found informational economies of scope between the two functions. For example, often the first thing a bank requires before giving credit is that the firm open an account so that the bank can monitor the firm's operations. In fact, one can regard deposit taking and credit lines as essentially the same operation: liquidity provision on demand. Imperfect correlation in these activities leads then to synergies (empirically documented by Kashyap, Rajan, and Stein 2002).

Most narrow banking proposals just push the fragility problem plus liquidity creation for firms to another level. For example, finance companies (for long-term projects) will provide liquidity financed by negotiable certificates of deposit, but this retains the coordination problem of investors. This means that narrow banking does not address the basic problem for which safety nets are intended: the adverse consequences of banking fragility in terms of credit supply and externalities for the private sector of the economy. A potential implication is that the commitment not to insure finance companies that take on the functions of banks may not be credible. In fact, one may believe the opposite. Narrow banking may encourage discretionary bailouts because it limits explicit insurance to the narrow bank, which is politically unrealistic given the need of a safety net for the banking system.

In conclusion, the narrow banking proposal, in its strict form, does away with the main function of banks and, therefore, will probably be particularly detrimental to emerging market economies, where financial markets are less developed and securitization is less advanced. In contrast, narrow banking in its softer forms may be appropriate for economies with well-developed financial systems such as in the United States, where liquidity is abundant. In fact, money market funds are providing more and more transaction services in the United States. Put another way, emerging market economies have a greater need for bank monitors to finance and elicit returns from entrepreneurial projects. It is also true that emerging market 
economies with a market discipline problem may need to place some asset restrictions on banks' balance sheets to control risk taking. Restrictions may be minimum diversification levels, limitations on concentration of risks, growth capacity of loans in new areas, and so on. This goes some way toward the narrow banking proposal, in the sense of restricting risk taking on the asset side, but without terminating the financing of illiquid loans with deposits.

At the same time there are more limited forms of narrow banking that allow informational economies of scope between deposits and loans to be preserved. For example, banks could be allowed to offer narrow bank accounts, essentially money market funds insured only against fraud, on top of their "standard" uninsured deposits and loan provision facilities (Mishkin 1999a, Mishkin 1999b). This proposal apparently limits the cost of deposit insurance, but incentives would still remain to bail out the non-narrow part of the bank because of the adverse consequences of a failure for the economy.

It may help think counterfactually what would have happened if narrow banks had been in place in Argentina during the currency board regime. Would the banking crisis have been averted? Probably not. Consider first the orthodox form of a narrow bank as a separate institution investing deposits in safe short-term assets (such as U.S. Treasury bills). In this situation there would be a run only if there is a fear of confiscation (for example, with forced conversion of dollar deposits into depreciated pesos). The rational reason for the fear is that with an unsustainable currency board, banks and finance companies that provide loans to firms and consumers will be in trouble anyway. Narrow banking may make this confiscation more difficult, or more evident, but may not be able to avoid it. In a crisis situation with weak property rights, the pressure to capture the sound assets of the narrow bank may just be too great. A softer form of narrow banking with narrow accounts in a multipurpose bank may be more vulnerable. However, even if depositors would not have run on narrow banks, the collapse of the currency board would have induced default on dollar-indebted agents and therefore brought down the financial institutions that lent to them. At best, the crisis is transferred to another level, which means that the cost of the crisis is shifted to the investors or depositors in the financial companies that lend to the private sector.

This discussion points to the fact that the first problem to be solved in an emerging market economy is, in many instances, political: to insure property rights so that depositors are confident that the contract with their bank will be respected and that the rules of the game are not changed in the middle of play. Narrow banking may help somewhat but need not solve this problem.

Second, an emerging market economy needs both an efficient payment and a transaction system and good facilities for credit that help sustain growth in the long term. The banking system should focus on both functions. This discards "strong" forms of narrow banking where deposit institutions are separated from 
credit institutions. An emerging market economy needs the classical function of banks. ${ }^{9}$

\section{A Monetary Union}

Another way to import discipline is by transferring some political sovereignty by forming a monetary union with other countries (such as Mercosur in trade, for example) and establishing an independent central bank. This solution is likely to be problematic, however, mainly because it is not clear how to build an independent central bank from the monetary union of countries whose central banks have shaky reputations. For example, the European Monetary Union (EMU) would probably not have arisen had not the Bundesbank had such strong anti-inflationary credentials.

Another issue is that the organization of the lenders of last resort in a monetary union with no central political authority is likely to be contentious as, again, the EMU shows. A decentralized organization for the lenders of last resort raises serious issues of effectiveness, whereas a centralized organization needs to clarify the fiscal issue (who will pay for institutions that end up insolvent) and determine in what situations the centralized lender of last resort will not help (a systemic problem in a small country may not be systemic in the larger area of the monetary union, for example). (See Vives 2001 for a discussion of those issues in the European context.) The experience of the EMU points to the difficulties that advanced economies with well-developed institutions face in establishing a common central bank. At the present stage in Latin America, the avenue of a monetary union does not seem realistic.

\section{Foreign Banks}

It may be thought that with an external discipline and a banking system mostly in foreign hands, stability should be guaranteed because of the support provided by strong international banks supervised abroad and with the backing of their respective central banks. The Argentine crisis dispels this notion. While the headquarters of foreign banks would provide help to a subsidiary when a problem develops (because the brand name and the franchise value of the bank are at stake), this need not hold when a systemic problem develops. This is the more so if the systemic problem (due to the nonsustainability of the currency board arrangement) is compounded by confiscatory measures.

Furthermore, even if foreign bank headquarters were willing to help, they need not do so at the optimal social level, because they will not take into account the external effects of their help. For example, the headquarters of foreign banks may want to limit their exposure to a country that may face a currency crisis and therefore will tighten liquidity provision to branches or subsidiaries in the country. (There is an important distinction between a branch and a subsidiary: headquarters have to back the deposits in a branch but need not do it for a subsidiary.) 
Furthermore, the incentives of the foreign lender of last resort and supervisor are not necessarily in line with local interests. A foreign supervisor will not take into account the consequences (systemic or not) for domestic residents of a restructuring of a local branch or subsidiary. The foreign supervisor will care only about the consequences for systemic stability at home of a crisis of a subsidiary abroad.

Foreign banks are thus no panacea for solving the lender of last resort and supervisory problems in an emerging market economy. Whereas successful in Panama, which has no lender of last resort facility except, seemingly, a large U.S. bank (Chapman 1999; Moreno-Villalaz 1999), Panama is not a typical emerging market economy.

Furthermore, some research using Argentinean data claims that large foreignowned institutions concentrate on large projects and may have trouble providing relationship loans to opaque small firms (Berger, Klapper, and Udell 2001). If confirmed, this may call for an appropriate balance of foreign and local institutions or at least for the use by foreign banks of local subsidiaries rather than branches. A local subsidiary typically comes from the foreign bank's acquisition of a local bank and, therefore, at least part of the informational capital of the local bank should be incorporated into the new or transformed entity.

\section{Public Banks}

There is an agreement that public banks have been the worst performers in Argentina according to standard criteria (see, for example, Berger, Klapper, and Udell 2001) and that they were the principal cause of the run in 2001. The question is what role should public banks have in an emerging market economy. A theoretical case could be made for their role in extending credit where the market fails because of acute asymmetric information problems. However, the case for privatization is strong once it is acknowledged that public banks are the main culprits behind the excessive bailout problem, with a destabilizing influence, and once the political economy issues are weighed in the balance. At the end of the day, the public sector cannot provide what the private sector has failed to provide.

Mandating a narrow bank charter for public banks limits their exposure but at the same time removes their only potentially redeeming value: providing loans to informationally opaque business. Private banks can provide subsidized credit to families and firms, as well as "universal service" for transaction accounts, if deemed necessary. The proper way to do this is to auction the service to well-capitalized private institutions. If the privatization route is taken, attention should be paid to ensure that prospective bidders have enough capability and local knowledge to provide the required relationship-based banking services so crucial to small business. 


\section{Offshore Banking}

Offshore banking consists of the provision of financial services and cross-border intermediation of funds to nonresidents by banks residing in offshore financial centers. Offshore financial centers are characterized by low levels of regulation and information disclosure and tend to be tax havens.

During the Tequila crisis offshore establishments of Argentine banks suffered a run parallel to the onshore run. Several offshore institutions and their onshore parents failed, and investors onshore were left in a weak position to claim assets, because the offshore institutions were in different jurisdictions (Errico and Musalem Borrero 1999).

As with narrow banking, with offshore banking the institutional credibilityconfiscation problem is alleviated, in this case more substantially, but it is not completely solved. The question is whether offshore arrangements can be designed so that it becomes difficult to confiscate the monies once they reach national soil. A benefit of offshore banking is then to alleviate the confiscation problem. However, with offshore banking the benefit of a banking system close to business would be lost, and the additional cost of operation in a different jurisdiction should be added to this.

\section{The Role of an International Agency}

There are two types of market failures that an international agency such as the IMF may help overcome. The first is the coordination problem faced by international investors in a crisis situation. The second is the commitment problem of domestic institutions such as a national central bank. The two are intertwined and, as we will see, the first may help alleviate the second. The reason is that an ex post coordination failure may help create ex ante incentives.

An international agency, combining the functions of crisis lender and crisis manager, may be helpful provided it is complemented with a policy of prompt corrective action and facilities for orderly failure resolution.

The IMF has typically relied on ex post policy conditionality for granting help to a country - that is, the need for a country to commit to follow certain policies to be helped after a crisis. Although the IMF can ask for collateral, it rarely does. The reason is that the IMF is seen as a preferred creditor: not repaying the IMF essentially means being denied access to the international capital market. At the same time the IMF has also played a role as crisis manager in negotiating the way out of crisis and helping to set up financial packages (Fischer 1999).

An international lender of last resort-whether helping countries in trouble much the way a central bank helps individual banking institutions, coordinating the 
interventions of the three main central banks, or acting as a global central bank issuing an international currency — can follow a policy of injecting liquidity in international financial markets (see Eichengreen 1999 for a survey of the different proposals). The last approach is developed in several proposals that adapt Bagehot's doctrine to international lending. The Report of the International Financial Institution Advisory Commission (IFIAC 2000), chaired by Allan H. Meltzer, recommended that the IMF lend according to Bagehot's rules: lending at a penalty rate with collateral only to a set of countries that meet certain requirements in their banking systems (adequate capitalization of domestic banks, free entry of foreign banks) as well as having a commitment to fiscal standards and to reporting accurate financial information. A significant difference between the approaches is on the required size of the international lender of last resort (Jeanne and Wyplosz 2001). In the first case an issuer of international currency is needed, whereas in the second the intervention is bounded by the difference between the short-term foreign exchange liabilities of the banking sector and the foreign reserves of the country in question.

Consider the more realistic second approach. The main tension identified in the debate is between those who emphasize the crisis prevention effect of liquidity support (Fischer 1999) and those who are worried about generating moral hazard in the country being helped (IFIAC 2000). This reflects the tension between the need to provide ex ante incentives to the country to limit moral hazard and the need to provide help once the crisis occurs.

The conceptual framework is as described earlier for an emerging market economy that has acquired foreign-denominated short-term debt to alleviate the moral hazard and commitment problem to access the international capital market (Rochet and Vives 2004). When returns are below a certain threshold, projects should be restructured to provide incentives to exert effort. This second-best solution can be implemented with the help of an international agency. The following scenarios can be considered:

- No bail-in, no bail-out. With no international lender of last resort and interrupted access to international capital markets, country projects are liquidated whenever withdrawals by foreign fund managers are larger than foreign reserves. This limits investment.

- Bail-in, but no bail-out. With no international lender of last resort but access to international capital markets, some costly project liquidation is avoided with fire sales of assets, but excessive liquidation of entrepreneurial projects will still typically occur.

- Bail-in and bail-out. An international agency with crisis lender and crisis manager roles can complement country access to international capital markets to enforce this second-best solution. The appropriate policy should depend on the extent of the moral hazard problem in the country considered. 
When the moral hazard problem in the country is severe, a policy of prompt corrective action whenever the country is close to insolvency is needed to complement the international lender of last resort facility. A solvent country may need to restructure when returns are close to the solvency threshold.

When the moral hazard problem in the country is moderate, in addition to the international lender of last resort help for a solvent country, an orderly resolution of the failure process or help is needed for an insolvent country that is close to the solvency threshold. This may be interpreted as a mechanism similar to the sovereign debt restructuring mechanism of the sort considered by the IMF with the objective of restructuring unsustainable debt. ${ }^{10}$

An international lender of last resort that follows a modified Bagehot's prescription complemented by prompt corrective action and orderly failure resolution facilities can implement a second-best solution provided that it is well informed about country returns. One possibility is that the international lender of last resort does indepth country research and has supervisory knowledge of the banking system of the country where the crisis occurs. This international lender of last resort should also have statutory independence (along the lines of, for example, De Gregorio and others 1998) that allows building a reputation for not granting help when it is not ex ante efficient to do so and thereby not contributing to moral hazard. Ex ante conditionality in terms of the rule of law and accounting standards makes sense because they contribute to assessing the extent of the moral hazard problem in the country and, therefore, the appropriate policy.

Furthermore, the international lender of last resort should provide a loan only when the country has enough international collateral. The critical amount of collateral should be determined by the financial position associated with the return below which help should not be provided. Obviously, to determine the minimum required amount of collateral (and the range where help has to be provided), we need the supervisory knowledge of the economy. A minimum amount of collateral is established not to secure the loan but to impose a threshold below which help is not given.

\section{Policy Recommendations and Issues for Further Research}

The underlying problems of regulation are the same in industrial countries and developing countries and emerging market economies. However, in developing countries and emerging market economies, the asymmetric information problems are more acute, and the institutions are weak. Several consequences follow from this.

First, regulation must be adapted because reliance on transparency and disclosure requirements as well as risk-based insurance is limited. This means in particular that capital requirements will need to be tuned to the emerging market economy context 
and complemented by other types of restrictions on the activity of financial institutions. At the same time the cost of the liquidation of projects or the social cost of failure may be larger in developing countries and emerging market economies. This calls for moderating competitive pressures and market discipline.

A second consequence is that the policy commitment problem of domestic institutions becomes central. From this it follows that developing countries and emerging market economies need to import external discipline. This can be accomplished by acquiring foreign short-term debt. The analysis provides rough guidance on the optimal amount of external discipline that is good for a country as a function of the severity of the moral hazard problem and the cost of liquidating projects. There is a middle range of countries - where the moral hazard problem is significant but not extreme and the cost of liquidating projects is moderate - for which importing external discipline is worthwhile.

A corollary of the analysis is that developing countries and emerging market economies need differentiated treatment not only from developed economies but also among themselves, especially with respect to the levels of external discipline.

Finally, international institutions such as the IMF may be instrumental in helping emerging market economies overcome the commitment problem. However, several requirements need to be met: the institutions should be independent; they should lend conditionally on the institutional structure of the country (not on policy); and they should require collateral (not to insure repayment but as incentive).

Many issues need further research, including the optimal regulatory policy mix for every stage of development and the quality of the institutional structure; the interplay between the coordination problem causing fragility in the banking and financial system, and the moral hazard problem caused by bailouts in response to fragility; and the determinants of the optimal level of short-term foreign debt for a small open economy with a policy commitment problem.

\section{Notes}

Xavier Vives is Professor of Economics and Finance at IESE Business School, University of Navarra, Barcelona, and Research Professor at Institució Catalana de Recerca i Estudis Avançats-Universitat Pompeu Fabra (UPF); his email address is xvives@iese.edu. The author is grateful to the World Bank and the Inter-American Development Bank for support on projects related to this article as well as to project SEJ2005-08263 at UPF of the Directorate-General for Research of the Spanish Ministry of Education and Science. The article draws on the author's joint work in banking with Douglas Gale, Carmen Matutes, and Jean-Charles Rochet. The author is grateful to Ramon Caminal, Fernando Broner, Eduardo L. Yeyati, three referees, and Shanta Devarajan for helpful comments.

1. For the Argentina case Calomiris and Powell (2000, p. 1) argued that "the banking sector suffered from ineffective regulation and supervision and repeated, forced government rescues contributed significantly to Argentina's past fiscal and inflationary problems."

2. Moral hazard refers to the effects that insurance may have on the behavior of people with insurance, who may take greater risks than they would without it because they know they are protected, with adverse consequences for the insurance company. The problem arises because the insurance 
company cannot observe the effort the agent makes to prevent a loss. In economic analysis moral hazard refers to hidden actions in a contractual relationship. Adverse selection arises when the insurer knows more than the company about the probability of the loss happening. It is an issue of hidden information. In general adverse selection involves the adverse consequences for uninformed parties of the actions of privately informed ones. These asymmetric information problems are documented for a range of emerging market economies later in the article.

3. The demand deposit contract, redeemable at par, either creates a coordination problem for investors that does not allow bankers to extort rents on their abilities to collect illiquid loans (Diamond and Rajan 2001) or disciplines bank managers subject to a moral hazard problem (Calomiris and Kahn 1991; Gale and Vives 2002).

4. Moral hazard may also arise from the side of the entrepreneur asking for credit to finance a project. If effort is devoted to the project, returns are improved. If the entrepreneur takes a loan that is forcibly short term, the threat of liquidation if the returns (which are not verifiable) are low and cannot cover the promised debt payment provides the incentive for effort in the project. Effort improves returns, but liquidation is costly.

5. Postlewaite and Vives (1987) provided an early model with a unique equilibrium, where the probability of a crisis is determined by the realization of the liquidity needs of depositors, which are private information.

6. In the presence of a moral hazard problem efficiency (of the second-best type because of incentive considerations) requires that the expected utility of investors and depositors be maximized subject to the constraint that the bank manager exerts effort. This can be accomplished by liquidating the project when observable interim returns are lower than a certain threshold (this is the minimal threshold that induces the manager to exert effort; a higher threshold would just increase the costs associated with liquidation). The issue is how to achieve or approximate this second-best outcome. This is discussed again in the following sections.

7. The charter value is the franchise value of the bank (forward-looking capitalized discounted expected profits). It can be measured by the market to book asset ratio. A high charter value means that the bank has a lot to lose if closed.

8. Rodrik and Velasco (1999) also found that a greater short-term exposure aggravates the crisis once capital flows reverse.

9. See Fernandez and Schumacher (1997) for a more positive view of narrow banking for Argentina.

10. Bolton (2003) discussed sovereign debt restructuring mechanisms from the perspective of corporate bankruptcy theory and practice.

\section{References}

Allen, F., and D. Gale. 2001. "Financial Contagion.” Journal of Political Economy 108(1):1-33.

Allen, F., and A. Santomero. 2001. "What Do Financial Intermediaries Do?" Journal of Banking and Finance 25(2):271-94.

Berger, A. N., L. F. Klapper, and G. F. Udell. 2001. "The Ability of Banks to Lend to Informationally Opaque Small Businesses.” Journal of Banking and Finance 25(12):2127-67.

Bernanke, B., and M. Gertler. 1989. "Agency Costs, Net Worth, and Business Fluctuations.” American Economic Review 79(1):14-31.

Bolton, P. 2003. "Toward a Statutory Approach to Sovereign Debt Restructuring: Lessons from Corporate Bankruptcy Practice around the World.” IMF Staff Papers 50 (Special Issue):41-71.

Bolton, P., and D. Scharfstein. 1990. "A Theory of Predation Based on Agency Problems in Financing Contracting.” American Economic Review 80(1):93-106. 
Broner, F., G. Lorenzoni, and S. Schmukler. 2004. "Why Do Emerging Economies Borrow Short Term?” Economics Working Papers 838. Department of Economics and Business, Universitat Pompeu Fabra, Barcelona.

Caballero, R., and A. Krishnamurthy. 2002. "A 'Vertical' Analysis of Monetary Policy in Emerging Markets." MIT Department of Economics Working Paper 02-16. Cambridge, Mass.

_. 2003. "Excessive Dollar Debt: Financial Development and Underinsurance.” Journal of Finance 58(2):867-93.

Calomiris, C., and C. Kahn. 1991. "The Role of Demandable Debt in Structuring Optimal Banking Arrangements.” American Economic Review 81(3):497-513.

Calomiris, C. W., and A. Powell. 2000. "Can Emerging Market Bank Regulators Establish Credible Discipline? The Case of Argentina 1992-1999." NBER Working Paper 7715. National Bureau of Economic Research, Cambridge, Mass.

Calvo, G., and E. Talvi. 2005. "Sudden Stop, Financial Factors and Economic Collapse in Latin America: Learning from Argentina and Chile." NBER Working Paper 11153. National Bureau of Economic Research, Cambridge, Mass.

Calvo, G., A. Izquierdo, and E. Talvi. 2003. "Sudden Stops, the Real Exchange Rate and Fiscal Sustainability: Argentina's Lessons.” NBER Working Paper 9828. National Bureau of Economic Research, Cambridge, Mass.

Chapman, G. 1999. "La Experiencia de Dolarización en Panamá." Paper Presented at the Conference on Opciones Cambiarias para la Región, Sponsored by the Inter American Development Bank, July 23-24. Panama City.

Cordella, T., and E. L. Yeyati. 2002. "Financial Opening, Deposit Insurance, and Risk in a Model of Banking Competition.” European Economic Review 46(3):471-85.

Cukierman, A. 1992. Central Bank Strategy, Credibility, and Independence: Theory and Evidence. Cambridge, Mass.: MIT Press.

De Gregorio, J., Eichengreen, B., Ito, T., and C. Wyplosz. 1998. An Independent and Accountable IMF: Geneva Reports on the World Economy, 1. Oxford: Information Press.

Detragiache, E., and S. Spilimbergo. 2004. "Empirical Models of Short-term Debt and Crises: Do they Test the Creditor Run Hypothesis?” European Economic Review 48(2):379-89.

Diamond, D., and P. Dybvig. 1983. "Bank Runs, Deposit Insurance, and Liquidity.” Journal of Political Economy 91(3):401-19.

Diamond, D., and R. Rajan. 2000. “A Theory of Bank Capital.” The Journal of Finance 55(6):2431-65.

Diamond, D. W., and R. Rajan. 2001. "Liquidity Risk, Liquidity Creation and Financial Fragility: A Theory of Banking." Journal of Political Economy 109(2):287-327.

Eichengreen, B. 1999. Toward a New International Financial Architecture: A Practical Post-Asia Agenda. Washington, D.C.: Institute for International Economics.

Eichengreen, B., and A. Rose. 1998. "Staying Afloat When the Wind Shifts: External Factors and Emerging-Market Banking Crises." CEPR Discussion Paper 1828. Centre for Economic Policy Research, London.

Errico, L., and A. Musalem Borrero. 1999. "Offshore Banking: An Analysis of Micro-and MacroPrudential Issues.” IMF Working Paper 99/05. International Monetary Fund, Washington, D.C.

Fernandez, R., and L. Schumacher. 1997. “Does Argentina Provide a Case for Narrow Banking?” In S. K. Bery and V. F. Garcia, eds., Preventing Banking Sector Distress and Crises in Latin America: Proceedings of a Conference Held in Washington, D.C., April 15-16, 1996. Discussion Paper 360. World Bank, Washington, D.C.

Fischer, S. 1999. "On the Need for an International Lender of Last Resort." Journal of Economics Perspectives 13(4):85-104. 
Frankel, J., and A. Rose. 1996. "Currency Crashes in Emerging Markets: An Empirical Treatment." Journal of International Economics 41(3-4):351-66.

Friedman, M. 1959. A Program for Monetary Stability. New York: Fordham University Press.

Gale, D., and X. Vives. 2002. "Dollarization, Bail Outs, and the Stability of the Banking System." Quarterly Journal of Economics 117(2):467-502.

Goldstein, I., and A. Pauzner. 2005. "Demand Deposit Contracts and the Probability of Bank Runs." The Journal of Finance 60(3):1293-327.

Gorton, G. 1985. "Bank Suspension of Convertibility.” Journal of Monetary Economics 15(2):177-93.

—. 1988. "Banking Panics and Business Cycles.” Oxford Economic Papers 40(4):751-81.

Hart, O. 1995. Firms Contracts and Financial Structure. Oxford: Clarendon Press.

Hellmann, T. F., K. Murdock, and J. Stiglitz. 2000. "Liberalization, Moral Hazard in Banking, and Prudential Regulation: Are Capital Requirements Enough?” American Economic Review 90(1):147-65.

Holmström, B., and J. Tirole. 1997. "Financial Intermediation, Loanable Funds and the Real Sector." Quarterly Journal of Economics 112(3):663-91.

—. 1998. "Private and Public Supply of Liquidity." Journal of Political Economy 106(1):1-40.

IFIAC (International Financial Institution Advisory Commission). 2000. "Report of the International Financial Institution Advisory Commission." Allan H. Meltzer, Chair, Washington, D.C.

Jacklin, C., and S. Bhattachrya. 1988. "Distinguishing Panics and Information-Based Bank Runs: Welfare and Policy Implications.” Journal of Political Economy 96(3):568-92.

Jeanne, O. 2000. "Foreign Currency Debt and the Global Financial Architecture." European Economic Review 44(4-6):719-27.

Jeanne, O., and C. Wyplosz. 2001. "The International Lender of Last Resort: How Large is Large Enough?” CEPR Discussion Paper 2842. Centre for Economic Policy Research, London.

Kaminsky, G., and C. Reinhart. 1999. “The Twin Crises: The Causes of Banking and Balance-of-Payments Problems." American Economic Review 89(3):473-500.

Kashyap, A. K., R. Rajan, and J. Stein. 2002. "Banks as Liquidity Providers: An Explanation for the Coexistence of Lending and Deposit-Taking." The Journal of Finance 57(1):33-73.

La Porta, R., F. Lopez-de-Silanes, A. Shleifer, and R. Vishny. 1998. “Law and Finance.” Journal of Political Economy 106(6):1113-55.

Litan, R. 1987. What Should Banks Do? Washington, D.C.: Brookings Institution Press.

Matutes, C., and X. Vives. 2000. "Imperfect Competition, Risk Taking and Regulation in Banking." European Economic Review 44(1):1-34.

Mishkin, F. 1999a. "Financial Consolidation: Dangers and Opportunities." Journal of Banking and Finance 23(2-4):675-91.

—. 1999b. "Lessons from the Tequila Crisis.” Journal of Banking and Finance 23(10):1521-33.

Moreno-Villalaz, J. L. 1999. "Lessons from the Monetary Experience of Panama: A Dollar Economy with Financial Integration.” CATO Journal 18(3):421-39.

Morris, S., and H. S. Shin. 2000. "Rethinking Multiple Equilibria in Macroeconomic Modelling." Cowles Foundation Discussion Papers 1260. Cowles Foundation, Yale University, New Haven.

Nakamura, L. 1988. "Loan Workouts and Commercial Bank Information: Why Banks Are Special." Working Paper 89-11. Federal Reserve Bank of Philadelphia.

Petersen, M., and R. Rajan. 1994. "The Benefits of Lending Relationships: Evidence from Small Business Data." Journal of Finance 49(1):3-37.

Postlewaite, A., and X. Vives. 1987. "Bank Runs as an Equilibrium Phenomenon.” Journal of Political Economy 95(3):485-91. 
Powell, A. 2001. “A Capital Accord for Emerging Economies?” Policy Research Working Paper 2808. World Bank, Washington, D.C.

Pulley, L. B., and D. B. Humphrey. 1993. "The Role of Fixed Costs and Cost Complementaries in Determining Scope Economies and the Cost of Narrow Banking Proposals." Journal of Business 66(3):437-62.

Radelet, S., and J. D. Sachs. 1998. "The East Asian Financial Crisis: Diagnosis, Remedies, Prospects.” Brookings Papers on Economic Activity 28(1):1-74.

Rochet, J. C., and X. Vives. 2004. "Coordination Failures and the Lender of Last Resort: Was Bagehot Right After All?" Journal of the European Economic Association 2(6):1116-47.

Rodrik, D., and A. Velasco. 1999. "Short-Term Capital Flows“. NBER Working Paper 7364. National Bureau of Economic Research, Cambridge, Mass.

Sachs, J., A. Tornell, and A. Velasco. 1996. "Financial Crises in Emerging Markets: The Lessons from 1995.” NBER Working Paper 5576. National Bureau of Economic Research, Cambridge, Mass.

Tirole, J. 2002. Financial Crises, Liquidity, and the International Monetary System. Princeton, N.J.: Princeton University Press.

Vives, X. 2001. "Restructuring Financial Regulation in the European Monetary Union.” Journal of Financial Services Research 19(1):57-82.

—. 2002. "External Discipline and Financial Stability." European Economic Review 46(4-5):821-8.

Wallace, N. 1996. "Narrow Banking Meets the Diamond-Dybvig Model." Federal Reserve Bank of Minneapolis Quarterly Review 20(1):3-13.

World Bank. 1998. “Argentina: Financial Sector Review.” Sector Report 17864. Washington, D.C. 